\title{
ИСПОЛЬЗОВАНИЕ ИК-ФУРЬЕ-СПЕКТРОСКОПИИ ДЛЯ АНАЛИЗА ПРЕПАРАТОВ НА ОСНОВЕ ЛИСТЬЕВ ЭВКАЛИПТА
}

\author{
Л.А. Яковишин \\ Кафедра химии и химической технологии, Севастопольский государственный \\ университет, 299053, Россия, Севастополь, ул. Университетская, 33.
}

DOI: 10.19163/MedChemRussia2021-2021-429

E-mail: chemsevntu@rambler.ru

Важным официнальным лекарственным растением является эвкалипт. Разработанные на его основе препараты широко используются в качестве антибактериальных и противовоспалительных средств [1]. Одним из таких лекарственных средств является хлорофиллипт. Считается, что он содержит хлорофиллы, однако в нем методами ТСХ и электронной спектроскопии были идентифицированы феофитинаты меди(II), но не найдены хлорофиллы $a$ и $b$ [1].

В настоящее время ИК-Фурье-спектроскопия начала активно использоваться для фармацевтического анализа лекарственных препаратов и субстанций, а также при оценке качества лекарственного растительного сырья [2-4].ИК-спектроскопия является одним из наиболее частотно используемых неразрушающих методов. Приставка НПВО дает возможность проводить ИКспектроскопическое исследование без специальной пробоподготовки, что существенно ускоряет фармацевтический анализ.

Нами проведено сравнение ИК-спектров хлорофиллипта нескольких производителей, суммы хлорофиллов и различных извлечений из листьев эвкалипта прутовидного. При этом наблюдаются как смещение ряда полос поглощения или изменение их интенсивности, так и отсутствие некоторых из них. Так, например, установлены отличия в частотах поглощения валентных колебаний связей О-Н и С-O, а также валентных колебаний связей $\mathrm{C}=\mathrm{C}$ и $\mathrm{C}=\mathrm{N}$ ароматических пиррольных колец. ИК-Фурье-спектроскопический анализ проведен с приставкой НПВО на алмазном кристалле.

\section{Литература}

[1] Т.А. Балаев, Б.Л. Молдавер, И.Б. Бадюгина, Фармация. 2008, 4, 13-16.

[2] А.П. Арзамасцев, Н.П. Садчикова, А.В. Титова, Хим.-фарм. журн. 2008, 42(8), 26-30.

[3] О.В. Тринеева, М.А. Рудая, А.А. Гудкова, А.И. Сливкин, Вестник Воронежского государственного университета. Серия: Химия. Биология. Фармация. 2018, 4, 187-194.

[4] Л.А. Яковишин, П.И. Бажан, В.Д. Ратников, В.И. Гришковец, Ученые записки Крымского федерального университета им. В.И. Вернадского. Биология. Химия. 2019, 5(3), 259-267. 